AgnieszKa Miksza

University of Lodz

\title{
EUROPEAN CULTURE AND ITS MULTIPLE VOICES
}

\author{
All objects, all phases of culture are alive. \\ They have voices. They speak of their history \\ and interrelatedness. \\ And they are all talking at once! \\ Camille Paglia
}

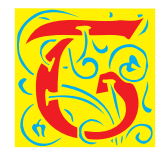

he above quotation highlights multiplicity of voices and interrelations within the notion of culture. The articles presented in the part entitled „European Culture and its Multiple Voices” highlight the fact that „[a]ll objects, all phases of culture are alive”. In the scope of its three main sections this part elaborates on topics concerning various aspects of European culture such as education, history, theatre, literature and social issues including gender, ageing, democracy and European Capitals of Culture. This series of engrossing papers is full of original statements and reflections. The Authors are preoccupied with ways of perceiving contemporary culture and, in addition, ask compelling questions about the future of our civilization.

The texts in the first section examine multiplicity of voices concerning the topic of education. The authors of the articles deal with 3D technologies at the service of culture (Fernando Blaya, Silvia Nuere and Manuel Islan) and democratic education in the EU (Denise Egea).

The subsequent section refers to theatre, literature and film. The authors present contemporary interpretations of ancient drama in Romanian (Iolanda Manescu). There is also an analysis of the American play by Arthur Miller Death of a Salesman (Per Grande). Moreover, film and opera are included in this section: Victor Castellani demonstrates how imagination and satire can tackle with inevitable monstrosity associated with Hitler. Finally, the topic of 
the small' and ,childlike' characters in Czech and Slovak literature is elaborated on by Verita Sriratana.

The final section is devoted to social issues and it presents articles dealing with e.g. transforming post-communist societies (Shala Barczewska) and European Capitals of Culture (Rolf Hugoson). What is more, gender and LGBTI issues are discussed by Veronika Plankova in her paper on 'enemies' of the Slovak society. Another social problem, ageing, is elaborated on in the article by Jenny Walden. This section also covers issues of Peloponnesian War (Anthi Dipla) and army jargon (Hans Rindisbacher).

All the sections of this part illustrate a wide range of notions and approaches which co-exist in European culture. They are simultaneous voices which „speak of their history and interrelatedness. And they are all talking at once!" 